\title{
Wearing the Cosmos: The High Priestly Attire in Josephus' Judean Antiquities
}

\author{
Joabson Xavier Pena \\ University of Groningen, Groningen, The Netherlands \\ joabsonpena@gmail.com
}

\begin{abstract}
In his recounting of the Exodus narrative of the making of the priestly vestments in Judean Antiquities 3.151-180, 184-187, Josephus provides a vivid description of the high priest's wardrobe, including its cosmological connotations. This article shows that Josephus uses cosmological motifs in his recounting of the high priestly attire in order to convey a message to his intended audience in Rome. Josephus adds his own accents to the biblical narrative to convince his public that the high priest's fine clothing functions as a statement that the Judean God is not a national deity with restricted power, but the Highest God, who is the only creator, maintainer, and supreme ruler of the universe. Seen from this perspective, we observe Josephus in dialogue with a wellestablished Greco-Roman clothing imagery tradition that portrays gods and mortals in symbolic garments to enhance their far-reaching power or authority.
\end{abstract}

\section{Keywords}

Flavius Josephus - Judean Antiquities - tent - high priestly attire - cosmos Judean God

\section{Introduction ${ }^{1}$}

In his recounting of the Exodus narrative of the wilderness tent in Ant. 3.108187, Josephus presents a distinctive description of the cult site as an archetype

1 This study was financed in part by the Coordenação de Aperfeiçoamento de Pessoal de Nível Superior - Brazil (CAPES) - Finance Code ooı. 
of the cosmos. ${ }^{2}$ Thus, when Josephus describes the physical structure of the tent, its appurtenances, and the priests' apparel, he also explains that everything within is in "imitation and representation of the universe" (Ant. 3.180). Josephus writes, for instance, that the types of material used to weave the tent's textile portion indicate the basic elements of nature from which God made the universe (3.183). The tripartite division of the tent reflects the cosmological geography: the land, the sea, and the sky $(3.123,181)$. The lampstand and the twelve loaves of bread within the tent signify heavenly bodies (3.144-146, $182)$, and the priestly vestments reflect the nature of the universe $\left(3.15^{1-180}\right.$, 184-187). The characterization of the sacred clothing is by far the longest, occupying two-fifths of the narrative, and most colorful account in Antiquities in which cosmological connotations appear prominently. ${ }^{3}$

Josephus' description of vestments for the priesthood has received limited attention from modern scholars. Among those few who deal with the priestly attire account in Antiquities, most have interpreted the narrative without considering Josephus' audience. Studies have tended to focus on the connection of this symbolic interpretation of the high priestly vestments with a Judean tradition of interpretation of biblical texts, rather than examination of how Josephus' intended audience may have understood the cosmological undertones of these distinctive vestments. ${ }^{4}$ Thus, this article aims to examine the narrative of the high priestly attire in Ant. 3.151-180, 184-187, considering two main questions: (1) What message was Josephus attempting to convey in his portrayal of the high priestly vestments in cosmic terms? (2) How would his public have comprehended the cosmological coloring of the sacred clothing?

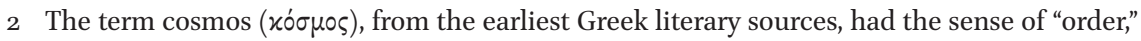
encompassing both the material and moral senses. "It was from this very idea of material and moral order that the meaning of kosmos expanded to signify form, government, decoration, and honour" (Marconi, "Kosmos," 211). Making use of these combinations of senses, philosophers from the sixth century вСЕ appropriated the term "for the grand structure of the earth, sea, and the sky above, encompassing by day the sun, clouds and rainbow, and by night the bright patterns of the moon, stars and planets" (Wright, Cosmology in Antiquity, 3). Pythagoras is believed to be the first philosopher to designate the whole system as the

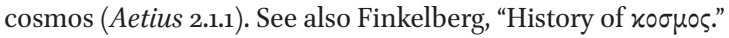

3 In our count, from a total of 3,297 words (Niese's editio maior) used for the portrayal of the tent, 1,342 words are related to the priests' clothing.

4 Among scholars who have written about the high priestly account in Antiquities are Nodet, Antiquités Juives, 157-64; Robertson, Ancient Israelite Tabernacle, 191-237, 259-61; Sanders, Judaism, 92-102; Hayward, Jewish Temple, 147-51; Feldman, Judean Antiquities 1-4, 271-82; Castelli, Antichità Giudaiche, 263-73, Gussmann, Priesterverständnis, 366-94; Weissenrieder, "Roadmap to Heaven." 
In order to properly address those questions, I begin by explaining that Josephus writes for a local audience in Rome, and so configures his portrayal of the high priestly attire in a language that they could understand. Also, I point out that the description of the sacred clothing occurs in a narrative context where Josephus seeks to convince his public that the high priest's fine clothing, with its embroidery and manifold ornaments, functions as a statement that the Judean god is not simply a national deity with restricted power, but the Highest God. I proceed with a detailed analysis of the account in Antiquities and how it connects with Josephus' depiction of God throughout the composition as a powerful deity of, and above, the whole universe, which he created and sustains. Next, I show that Josephus' representation of the high priestly vestments in cosmic terms is not a characteristic peculiar to this author or his Judean predecessors; in the Greco-Roman period, several gods and mortals were also described or depicted with similar language or garments. The article concludes by suggesting that Josephus, in his communication with a local group in Rome, wants to show that the high priest, as the only delegate of God on earth, bears in his clothing a statement of the universal power of the deity. Seen from this perspective, we observe that Josephus dialogues with a wellestablished Greco-Roman clothing imagery tradition that portrays gods and mortals in symbolic garments to enhance their far-reaching power or authority.

\section{The High Priestly Attire Account in Antiquities}

\subsection{Audience, Context, and Purpose}

In Antiquities' proem, Josephus mentions that he hoped for a Greek-speaking readership of his work (1.12). ${ }^{5}$ Although he states his intended audience for his composition, his real readership is likely made up of a local constituency. Steve Mason's investigations have demonstrated that Josephus' immediate audiences should be understood in light of the procedures followed for the creation, dissemination, and reading of literary works in ancient Rome. ${ }^{6}$ As Mason has noted, the idea of production of a book at that time was rather distinctive from the modern concept of publication: "The public envisaged by the ancient historian, the only people whose knowledge-base and tastes he could reliably anticipate, were those living around him. He knew many of them well,

5 See also Ant. 16.174; 20.262.

6 On the writing and circulation of texts in ancient Rome, see Vallette-Cagnac, Lecture $\grave{a}$ Rome, 157 . 
and others were acquaintances of friends."7 Following this line of reasoning, Josephus could be addressing his compositions to a restricted group in Rome that could include "some fellow-Judeans ... though he wrote with special concern for Greeks and Romans in the capital."8 While Josephus envisaged reaching a broad audience, aiming at eternity, in Lucian's words, it is conceivable that Josephus' major works were primarily addressed for a group of people in Rome who had interests in Judean history and traditions. ${ }^{9}$

This study agrees with the explanation Mason proposes. As we shall observe, the description of clothes in cosmic terms was a common tradition of the Roman imperial age. Considering that Josephus was writing from Rome and addressing his works to a local audience in the first instance, he adds his own accents to the biblical narrative of the making of the high priestly vestments in a language they could understand.

In following the text of Exod 25-30, 36-40, Josephus places the description of the sacred clothing within the account of the fabrication of the tent, which in turn is part of the story of the giving of the law to Moses in the wilderness. Josephus explains that after Moses stayed on Mount Sinai forty days and nights, he returned and revealed to the Hebrews that God had "advised him in what manner they would be happy in their form of government," as well as of his desire for a tent (Ant. 3.99-100).10

In the account of the tent, Josephus' Moses says that the layout and appurtenances should be in line with what "[God] himself had indicated" (3.101). Josephus emphasizes the divine instructions for the building of the tent. Elsewhere, he notes that Moses appointed Bezalel and Oholiab as "supervisors for the works, in accordance with the instruction of God." He also states that "Moses, in accordance with the direction of God, instructed them in all the details concerning the measurements and the size and what vessels it had to contain for the one who would attend to the sacrifices" $(3.104,107)$.

After that, Josephus goes on to describe the tent. He begins with the court (3.108-114), the exterior (3.115-121), and the interior (3.122-123), continuing to the furnishings $(3.124-150)$, and the garments of the priests $\left(3.15^{1-179)}\right)$. After

7 Mason, History of Jewish War, 80.

8 Mason, "Audience and Meaning," 73, 79. For Antiquities, in particular, see Mason, Introduction to Judean Antiquities, xvii-xx.

9 Lucian, Hist. cons. 40, 61; Mason, "Publication and Audiences." For objections to Mason's view, see Huitink and van Henten, "Publication." For alternative interpretations of Josephus' primary audience for Antiquities, see Bilde, Flavius Josephus, 102-3; Price, "Provincial Historian"; Castelli, Antichità Giudaiche, 26-28.

10 Translations follow Feldman, Judean Antiquities 1-4. 
outlining the characteristics of the cult site and the priestly attire, and before proceeding to the cosmological meaning of them (3.181-187), he comments:

One might wonder at the hatred of men toward us which they have continued to have on the ground that we belittle the Divinity that, indeed, they themselves have made up their minds to reverence. For if someone should investigate the construction of the tent and should observe the clothing and the vessels of the priest that we use for the sacred service, he would find that our lawgiver was a divine man and that the slanders that we hear from the others are unfounded. For he will find that each of these is in imitation and representation of the universe, if someone should be willing to consider them ungrudgingly and with understanding.

Josephus, Ant. 3.179-18o (Feldman, modified)

Josephus appears here to use the cosmological interpretation of the tent to refute the slurs and misconceptions against the Judeans throughout antiquity. Among those include the nature of God as misconstrued by outsiders, ${ }^{11}$ and the view that the native god of the Judeans had power only within a circumscribed geographic area. ${ }^{12}$ As a way to refute such slanders about Judean worship and enhance Moses' character, Josephus invites his readers to observe the structure of the tent, its contents, and the priestly garments he has just described. In this way, he remarks, the readers will find that the "lawgiver was a divine man."

Josephus continues here the discussion about the promulgation of the Judean politeia by Moses, which he had already initiated in Ant. 1. Like Philo, ${ }^{13}$ Josephus characterizes Moses as the only one who knew God's nature and mind and, who was capable of constructing a politeia that has its harmony with the nature of the universe as created by God $(1.15$; cf. $3.187 ; 4.180) .{ }^{14} \mathrm{He}$ writes that those who examine the Judean constitution "nothing will appear to them unreasonable or incongruous with the majesty and benevolence of God. For all things have their arrangement in harmony with the nature of the universe" (1.24).

Josephus' purposes are to show to his audience in Rome not only the superiority of the Judean politeia, as a constitution designed according to the cosmic law, but also that it reflects the nature of the Judean God as the only creator,

\footnotetext{
11 See Origen, Cels. 1.23; cf. Cook, Interpretation of Old Testament, 116.

12 See Julian, Contra Galilaeos 354a-c; cf. Cook, Interpretation of Old Testament, 275-76.

13 See, for instance, Philo, Creation 1-3; 143; Abraham 61; Moses 2.11-14, 48-49.

14 Regarding this view, see Holladay, Theios Aner, 102; Castelli, Antichità Giudaiche, 103; Mathews, Portrayal of Moses, 19-28.
} 
maintainer, and supreme ruler of the universe $(1.19,21) .{ }^{15}$ Considering that Mosaic law regulates the tent and the rituals performed within, it is rational to think of the cult site as an "imitation and representation of the universe" (3.180; cf. 3.123). Thus, the tent was not only a product of constitution that was in harmony with universal nature and drafted by the greatest sage and legislator who ever lived, but also was a dwelling built to celebrate the universal power of God. Those cosmic prerogatives of the Judean deity are distinctly evident in Josephus' description of the high priestly apparatus.

\subsection{Josephus' Portrayal of the High Priest's Wardrobe in Cosmic Terms}

As Josephus explains in his recounting of the Exodus narrative of the making of the priestly attire (Exod 28:1-43; 39:1-31), there were clothes ( $\sigma \tau 0 \lambda \alpha i),{ }^{16}$ both for the priests, whom the Judeans term "chaanaeae ( $\chi \alpha v a v \alpha i \alpha \varsigma)$," and the high

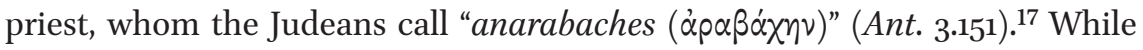
the ordinary priests' apparel was constituted of four linen garments (breech, tunic, belt, and cap), the high priest's wardrobe had the most elaborate attire, which comprised not only the four first linen garments of the ordinary priests, but also four more garments and accessories (tunic, ephod, breastplate, and golden crown) (Figure 1). ${ }^{18}$ Josephus' audience was familiar with most of the items of the priestly garments. Greco-Roman priests usually wore luxurious robes of white or purple, headbands, crowns, and waistbands. ${ }^{19}$

Josephus writes that before the priests and high priest performs the "sacred

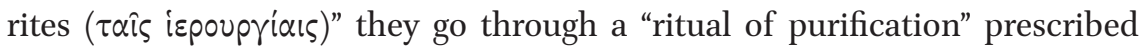
by the Law. After the purification ceremony, they dress themselves, putting on what is called "machanases ( $\mu \alpha \nu \alpha \alpha \dot{\alpha} \sigma \eta)$ ). This has as its meaning a pair of

15 The identification of the Judean law with cosmic law has Greco-Roman philosophical roots. The concept of cosmic/universal law, as elaborated by Greco-Roman philosophers, is based on the premise that there is a universal law, which is discernible only by reason. It is also in the universal law that the criteria for right and wrong can be found, and it is independent of human laws and customs. Being universal, it is valid everywhere and for everyone. See in this regard Stalley, Plato's Laws, 33; Brown, "Natural Law," 338; Hayes, Divine Law, 55 .

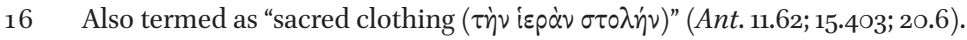

17 The words chaanaeae and anarabaches are Josephus' hellenised version of the Aramaic kahanaya (priests) and kahana rabba (high priest) (Thackeray, Jewish Antiquities, 1:387).

18 The book of Exodus refers to six high priest's garments (28:4). In the Mishnah, "the High Priest ministers in eight pieces of raiment, and a common priest in four-in tunic, drawers, turban, and girdle. To these the High Priest adds the breastplate, the apron, the upper garment, and the frontlet. In these were the Urim and Thummim inquired of; and they were not inquired of for a common person, but only for the king, for the court, or for one of whom the congregation had need" (m. Yoma 7:5, trans. Danby). Cf. Burkert, Greek Religion, 97; Lovén, "Clothing in Roman Cult.” 
drawers ( $\sigma u v \alpha \varkappa \tau \hat{p} \rho \alpha)$." According to Josephus, the item was "artfully fashioned ... from finely spun linen ( $\beta \dot{v} \sigma \sigma 0 v x \lambda \omega \sigma \tau \hat{\eta} \varsigma$ ), with the feet fitting into it just as into trousers. It ends above the waist and terminates at the flank, around which it is drawn tight" (3.152). Given that the biblical text only mentions linen undergarments (Exod 28:42 LXX $\pi \varepsilon p \downarrow \sigma x \varepsilon \lambda \hat{\eta} \lambda \iota v \hat{\alpha}$ ) that reached from hips to thighs, Josephus may be using his own experience as a priest in the Jerusalem temple for details in the description of the breeches. Josephus says nothing about the cosmological meaning of this article, probably because it was hidden from view.

Over the breeches, the priests wear "a linen garment of a double texture of

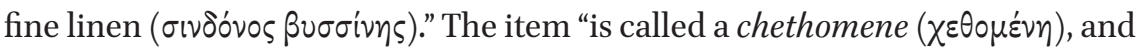
this signifies 'of linen.' For we call linen chethon ( $\chi \dot{\varepsilon} \theta 0 v) .{ }^{\prime 20}$ Josephus describes

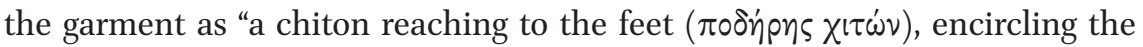
body and with tight-fitting sleeves around the arms" (3.153, modified). That the ordinary priests wore a chiton (or tunica in Latin) that falls over the feet is Josephus' own remark. The Septuagint records only a chiton $(\chi \vee \tau \dot{\omega} \omega)$ without giving its length (Exod 28:40). Josephus may have intended to enhance the dignity of the garment, because he had possibly once worn one when in service in the Jerusalem temple. ${ }^{21}$

He also writes that "the chiton is nowhere folded, but it has a wide opening at the neck and, by means of strings hanging from the border both at the breast and the back is tied fast above each shoulder. It is called massabazane ( $\mu \alpha \sigma \sigma \alpha \beta \alpha \dot{\nu \eta} \zeta) "$ (Ant. 3.156, modified). ${ }^{22}$ Josephus does not assign any cosmic symbolism to the garb, but it can be inferred that the linen textile indicates the earth. This suggestion may be inferred from Josephus comparison elsewhere of the linen with the earth (3.183). ${ }^{23}$ Additionally, garments made of linen were considered holy among the Egyptian priesthood and characterize heavenly beings in both the Hebrew Bible and the New Testament. ${ }^{24}$

The priestly belt ( $\tau \dot{\eta} \nu \zeta \dot{\omega} \nu \eta \nu)$ receives a fuller treatment. ${ }^{25}$ Josephus explains that the third article of clothing was girded at the breast, a little above the

$20 \quad$ The words chethomene and cheton are transliteration of the Aramaic ketôneth (tunic) and kitan (linen). Thackeray notes the relation that Josephus could have traced between the word chethomene and the Greek $\chi \imath \tau \dot{\omega} \omega$ used by Josephus below (Jewish Antiquities, 1:388).

21 See Josephus, J.W. 1.3.

22 For more details on the tunic, see Shlezinger-Katsman, "Clothing," 367-68.

23 See Sanders, Judaism: Practice and Belief, 97-98.

24 See Haran, Temples and Temple-Service, 174.

25 The Hebrew text of Exodus briefly describes this article of clothing as a "sash of fine twisted linen, and of blue, purple, and crimson yarns, embroidered with needlework" (39:29 NRSV). The LXX refers only to the sash in Exod 28:4, 39-40. 
arm-pit. It is four fingers wide, "woven coarse-meshed so as to seem like the skin of a serpent $\left(\lambda \varepsilon \beta \eta \rho^{\prime} \delta \alpha\right.$... ö $\left.\varphi \varepsilon \omega \varsigma\right)$. Flowers ( $\left.\alpha \dot{v} \theta \eta\right)$ are woven into it embroi-

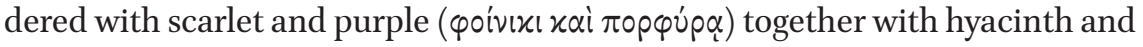

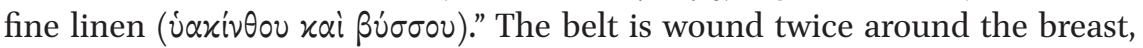
tied, and then hangs on one side to the ankles, "so long as the priest is performing nothing, for thus it presents a beautiful appearance to those who see it." Nevertheless, when the priest needs to perform the sacrifices, "in order that he may not be hindered in his work by its movement, he throws it over his left shoulder and carries it" $(3.154-155){ }^{26}$

The word used by Josephus to refer to the belt ( $\dot{\eta} \zeta \dot{\omega} \sim \eta)$, is the same employed in Exod 36:36 Lxx and Philo's Life of Moses (2.144). Nevertheless, he writes that Moses called the item abaneth, and in his days it is termed hemain (z) $\left.\mu^{\prime} \alpha \nu\right)$, "having learned it from the Babylonians" (Ant. 3.156). ${ }^{27}$ While Philo writes that the belt was used by the priests and high priest "to keep them unrestricted and readier for the holy services, by tightening the loose folds of the chitones" (Moses 2.144), Josephus is not clear about the function of the item; it appears, however, that the belt was basically decorative. ${ }^{28}$ Because of its type of woven fabric, Josephus writes that it has the appearance of "a serpent's skin $(\lambda \varepsilon \beta \eta p i \delta \alpha$ ... ö $\varphi \varepsilon \omega \varsigma)$." In addition to this fauna motif, Josephus writes that flowers were woven into it, decorated with scarlet, purple, hyacinth, and fine linen. ${ }^{29}$

The place of the belt around the priests' breast finds a parallel in the portrayal of heavenly beings in Revelation, as well as in some representations of Mithras. In Rev 1:13 is said that the Son of Man stands in the midst of seven

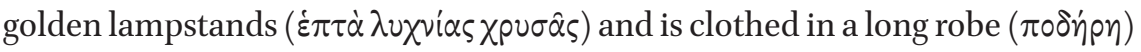

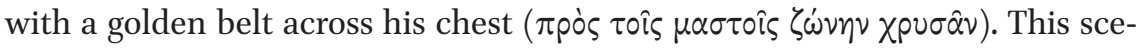
nario indicates the view of a priest officiating in the holy place. Elsewhere, the author describes seven angels coming from the heavenly temple and dressed in pure bright linen ( $\lambda$ ivov $x \alpha \theta \alpha \rho o$ $\nu \alpha \mu \pi \rho o ́ v)$, with golden belts around their

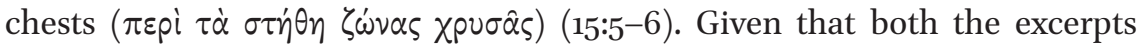
allude to a temple, they may be inspired by the figure of a Judean priest in the first century CE. Some depictions of Mithras also represent him with the

26 A significant difficulty with Josephus' depiction of the belt in Ant. is that it is different from the item referred in J.W. (5.232). Also, the description of this priestly belt does not appear elsewhere in the surviving Judean literature. Thus, we cannot say for sure whether Josephus is drawing from a Judean source or if this is his own creation.

27 Louis H. Feldman notes that when Josephus mentions Babylonians, he is referring to the Aramaic equivalent of the Hebrew word, as is also found in rabbinic literature (Judean Antiquities 1-4, 273 n. 401).

28 See Robertson, Ancient Israelite Tabernacle, 218.

29 Pausanias writes that on the golden robe of the statue of Zeus at Olympia are embroidered lily flowers (Descr. 5.11.1-2). 
accessory. The Mithraeum at Marino, for instance, shows a large fresco of Mithras in a red royal dress with a golden girdle around his chest. A marble relief found at Nesce (Italy) and a red relief in sandstone found in Neuenheim (Germany) also depict the Iranian god wearing the same accessory. ${ }^{30}$ Additionally, for a Roman reader, the belt around the chest of a person could indicate high rank and was usually worn by dignitaries and rulers. ${ }^{31}$

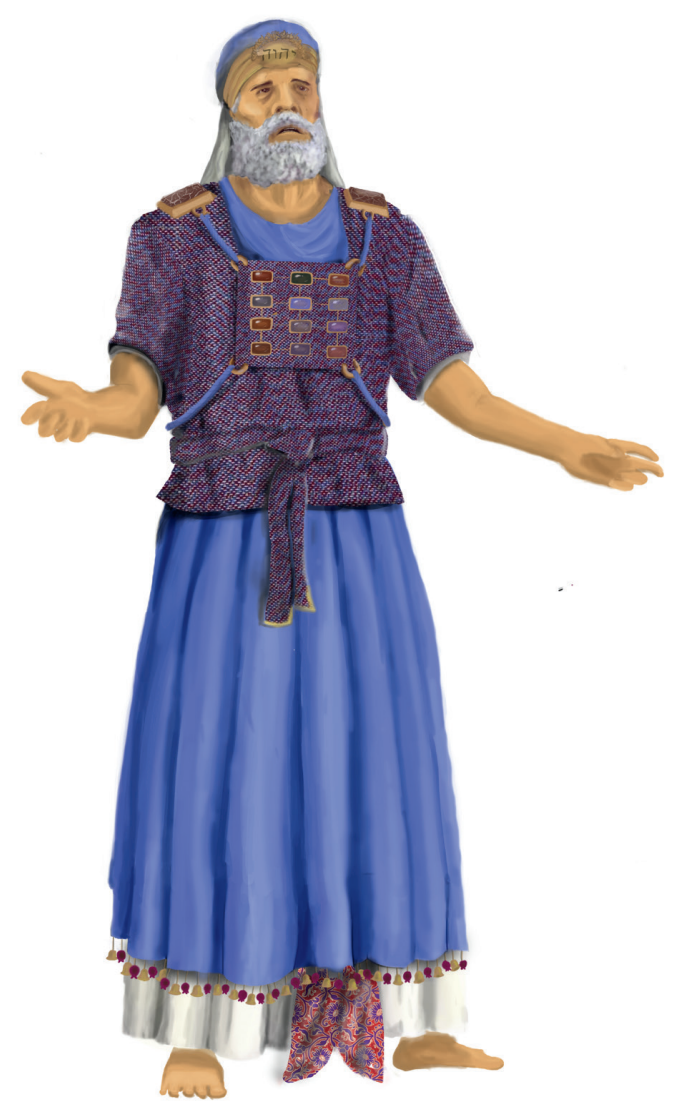

FIGURE 1 Conjectural portrait of Josephus' high priest

(Ant. 3.159-178)

DRAWING, COMMISSIONED BY THE AUTHOR

FROM THE ILLUSTRATOR GABRIEL COSTA ${ }^{32}$

30 See Aune, Revelation, 94.

31 See Osborne, Revelation, ch. 2.

32 This original color depiction attempts to build a picture of how Josephus saw the high priest's wardrobe. Despite the detailed description by Josephus in Ant., this reconstruction can only be an approximation. 
As part of his detailed cosmological interpretation of the priestly attire, Josephus declares that the belt, like the other clothing and the tent's fabric, in being made of four materials, indicates the nature of the four basic elements:

The pieces of cloth woven of four materials indicate the nature of the elements. The fine linen appears to indicate the earth because from it the flax grows; and the purple indicates the sea that has been reddened by the blood of the fishes. The hyacinth serves to indicate the air, and the crimson would be a symbol of fire.

Josephus, Ant. 3.183 (Feldman)

Oliver Gussmann suggests that Josephus appears to connect the fine linen (earth) and purple (sea) to the third day of the Genesis creation account. ${ }^{33}$ Even though Josephus' audience is aware that "[God] established the earth, pouring out the sea around it" on the third day (Ant.1.31), it is not clear whether Josephus wants to replay the creation narrative here in the tent's textiles.

The fourth item is the cap. Again, Josephus' description of the item exceeds the detail of the biblical texts, which mention only a cap made of linen (Exod 39:28). Josephus writes about a "peakless cap ( $\left.\pi \hat{\imath} \lambda \circ \check{\alpha}^{\alpha} x \omega \nu \circ \varsigma\right)$ " that covers most of the priest and high priest's head and is made of fine cloth ( $\sigma v \delta \delta \omega v)$, usually linen. This masnaephthes ( $\mu \alpha \sigma v \alpha \varepsilon \varphi \theta \hat{\eta} \varsigma$ ) is fashioned to resemble "a headband

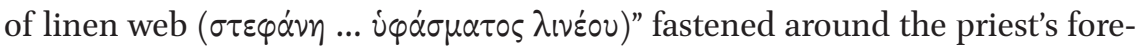
head $(3 \cdot 157-158)$. Henry St. J. Thackeray notes that the Hebrew word indicates in the biblical account the hat of the high priest, whereas here Josephus refers to the use of the item by both ordinary priests and high priest. ${ }^{34}$

After concluding the description of the four garments worn by both ordinary priests and the high priest, Josephus focuses on the last four articles of clothing worn exclusively by the high priest. Those distinctive multi-colored items are described as a spectacle worthy of the admiration of all. Given the status of the high priest, as God's only appointed delegate on earth responsible for sacrifices and prayers to the deity on behalf of the people and with a central role in divine-human communication $(3.188,191,214-217)$, Josephus makes clear to his Roman audience that the sumptuous and costly high priestly apparel holds a heavenly splendor. ${ }^{35}$ All the elaborate articles of clothing are symbolic of

33 Gussman, Priesterverständnis, 388.

34 Thackeray, Jewish Antiquities, 1:390-91.

35 The astonishment caused to those who saw the high priest in his full attire is captured by Sir 5o, Let. Aris. 96-99, and Philo, Spec. Laws 1.95 (Gussmann, Priesterverständnis, 383-85). 
the cosmos. They reveal God as a powerful deity who is the sole creator and maintainer of the whole universe.

Josephus explains that the high priest wears over the first linen chiton a

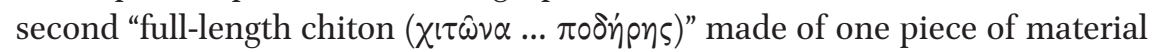
and of "hyacinth color." ${ }^{36}$ It is called "meeir ( $\left.\mu \varepsilon \varepsilon i p\right)$ " in Hebrew. ${ }^{37}$ The chiton is bound tightly with a belt ( $\dot{\eta} \zeta \dot{\omega} \sim \eta)$ similar in colors to the belt of the first tunic mentioned, except for the gold interwoven in the high priest's belt (3.159). While the Hebrew text of Exodus does not specify the length of the high priest's robe, it is not entirely clear why Josephus adds this particular detail for the high priest's tunic. Other Judean writers, including the Let. Aris. 96, Wis 18:24, and Rev 1:13, employ the same term.

Around the hem of the high priest's chiton were sewn fringes "in colour imitating the manner of pomegranates ( $\dot{\rho} \circ \hat{\omega} v$ ), and hung down, as well as golden

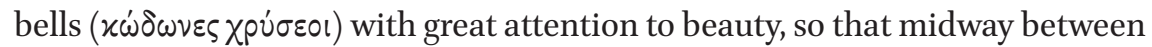
two bells there hung a pomegranate, and between the pomegranates a little bell ( $\left.\varkappa \omega \delta \omega^{\prime} v 10 v\right)$ " (Ant. 3.16o). ${ }^{38}$ While Josephus mentions fringes resembling pomegranates without giving their colors, the Hebrew text of Exodus refers to ornaments in the shape of pomegranates in blue, purple, and crimson yarns (28:33). In this way, Josephus may be agreeing with the text of the Septuagint, which describes fringes like pomegranates: "And you shall make on the hem of the undergarment below little pomegranates, as it were a flowering pomegranate tree" (Exod 28:29 LXx). Whereas the biblical account notes that the ornaments served to give a warning sound when the high priest was going into the holy place to minister before God, and when coming out (Exod 28:35), Josephus is silent about its purpose. ${ }^{39}$

The "high priest's chiton $(\chi \imath \tau \dot{\omega} \nu)$, , with its elaborate and precious ornaments, receives detailed cosmological treatment. Because the tunic is made of linen, it "signifies the earth." The hyacinth indicates "the vault of heaven." The bells and pomegranates attached to its hem are related to natural phenomena: the pomegranates resemble "lightning" and the bells through their sound "thunder" (Ant. 3.184).

$3^{6} \quad$ While the biblical text only records woven work in the opening for the head, Josephus is in accord with the rabbinic tradition (m. Yoma $72 \mathrm{~b}$ ). See also Feldman, Judean Antiquities 1-4, 274 ก. 418).

37 Meil (Exod 28:31 "robe").

38 Josephus' extra remarks about the little bell between the pomegranates do not find any parallel in the surviving Judean literature.

39 Plutarch seems to be the only gentile author to describe this priestly item. He writes that the high priest has "numerous bells ( $\kappa \omega \dot{\delta} \omega v \varepsilon \varsigma$ ) attached to his clothing and ringing below him as he walks" (Quaest. conv. 672a). 
Josephus' relation of the hem's ornaments with lightning and thunder seems to be connected with the understanding of these natural phenomena as the direct activity and manifestation of God. ${ }^{40}$ His audience was already familiar with this idea. In the episode of God's descent on Sinai, Josephus writes that "violent winds, rousing impetuous rain, came sweeping down, flashes of lighting caused fear to those who watched, and thunderbolts, having been poured down, revealed the presence of God" (3.79-80). In another place, Josephus dramatizes God's cooperation to the Hebrew leader Joshua in a battle through "thunder [and] the discharge of lightning bolts" (5.60). Josephus makes clear here as elsewhere that thunders and lightnings convey the power and majesty of God. ${ }^{41}$ God's power over this aspect of the natural world is also observed with the most important deity of the Greco-Roman pantheon; the Greeks called Zeus "God of Lightning and of Thunder" (Aristotle, [Mund.] 401a12). For the Romans, Jupiter Tonans ("Thunderer") has power over thunder and lightning (Silius, Punica 17.474-478; Suetonius, Aug. 29.3).

The most distinctive article of the high priest's apparel is worn upon the hyacinth chiton and is called, in Hebrew, the "ephod ( $\left.\dot{\varepsilon} \varphi \omega^{\prime} \delta \eta \nu\right)$." Josephus explains that it is fashioned like the Greek garb $\dot{\varepsilon} \pi \omega \mu^{\prime} \varsigma^{42}$ In Greek literature, this term denotes the part of the women's tunic that is tied on the shoulder by a brooch. The ephod is made of a piece of woven fabric the size of a cubit (equivalent to $44.36 \mathrm{~cm}$ ). It is made of different colors and golden threads, with an open space at mid-breast, and fitted out with sleeves. According to Josephus, it was made to have the appearance of a "chiton $(\chi \imath \tau \dot{\omega} \nu)$ " (Ant. 3.162). Elsewhere, he reads the ephod, or "outer vestment ( $\dot{\varepsilon} \varphi \alpha \pi \tau i \zeta)$," as "the nature of the universe ( $\tau \circ \hat{v} \pi \alpha \nu \tau \dot{s} \varsigma \tau \dot{\eta} \nu \varphi v ं \sigma \tau)$, which it seemed best to God to be made up of the four elements, interwoven with gold, in conception, I think, of the sunlight, which is available to all" (3.184).

Josephus' allusion to God's creation of the universe from the four elements could have reminded his audience of the demiurge of Plato's physical cosmos. In Timaeus, the Greek philosopher remarks that the cosmos came into existence through the creator-God's use of earth, air, fire, and water (31a-32d, 69 c). Josephus appears to characterize the Judean God as the demiurge when he writes that Abraham "was the first who dared to declare that God was the

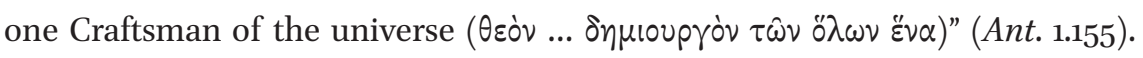

Raphael Patai proposes a different explanation for Josephus' cosmological reading of the bells and pomegranates. According to him, the sound-effects of the bells may be related to a rain-making ritual. The interpretation of the pomegranates as lightning may be associated with the light flashing from them (Man and Temple, 117).

41 Cf. Josephus, Ant. 1.203; 2.343-344; 6.27, 92.

42 The term is employed in Exod 28:4 LXX and Philo, Moses 2.110-111. 
Elsewhere, Isaac blesses Jacob by referring to God as the "Lord of all eternity

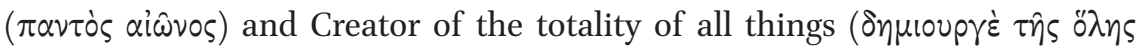

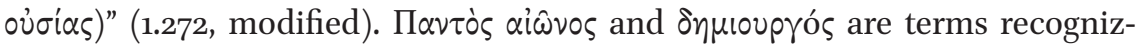
able from Plato's Timaeus 37d and 4oc. ${ }^{43}$ In his praise of God, Josephus' David addresses the deity as "the Creator of things human and divine ( $\delta \eta \mu$ lovprov ¿े $\theta \rho \omega \pi i v \omega \nu$ xai $\theta \varepsilon i \omega \nu)$ " (Ant. 7.380).

According to Josephus, the gold woven into the high priest's clothing means

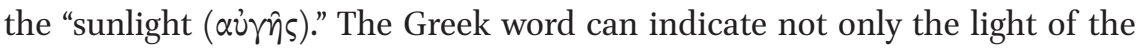
sun, but also splendor and brightness. Josephus appears to underscore the shine of the garments to emphasize the transformation experienced by the high priest when performing the sacred rituals before God, which brought upon the high priest the glory of the divine. ${ }^{44}$ Dazzling clothes reflecting sunlight and evoking divine glory arises in Josephus' account of King Agrippa I's attendance at a spectacle in Caesarea in honor of Caesar. Josephus writes that the king entered the theatre at daybreak arrayed in a robe

woven completely of silver so that its texture was indeed wondrous ... There the silver, illuminated by the touch of the first rays of sun ( $\tau \alpha i \varsigma$ $\pi \rho \dot{\omega} \tau \alpha \iota \varsigma \tau \hat{\omega} \nu \dot{\eta} \lambda \iota \alpha x \hat{\omega} \nu \dot{\alpha} x \tau i v \omega \nu)$, was wondrously radiant and by its glitter inspired fear and awe in those who gazed intently upon it. Straightway his flatterers raised their voices from various directions ... addressing him as a god.

JOSEPHUS, Ant. 19.343-345 (Feldman)

In Antiquities, Josephus tends to represent God by means of the sun, even though he acknowledges the Judean deity as the creator of the heavenly body (1.31). When positioning the entrance of the tent towards the rising sun, he explains "that the sun ( $\dot{0} \ddot{\eta} \lambda(0 \varsigma)$, when rising, might send its rays ( $\tau \dot{\alpha} \varsigma \dot{\alpha} x \tau i v \alpha \varsigma)$ first upon" the cult site (3.115). Josephus' editorial remark to the biblical text "suggests that the glory of God entered the tabernacle as the sun's rays shone in at dawn." ${ }^{55}$ Elsewhere, Josephus comments about King Uzziah's attempt to enter the holy place of the temple and offer incense. As a result of his impious act against God, "a great earthquake shook the earth and the sanctuary was

43 Cf. Feldman, Judean Antiquities 1-4, 107 n. 813.

44 A comparable case appears in Joseph and Aseneth (Warren, "Robe Like Lightning," 138-40).

45 Robertson, Ancient Israelite Tabernacle, 85. 
split open. A dazzling ray of sunlight shone through and fell on the face of the king, with the result of leprosy immediately appeared upon him" (9.224-225). ${ }^{46}$

Josephus writes that in the mid-chest gap of the ephod, there is an item with the dimension of a span (equivalent to $22.18 \mathrm{~cm}$ ). It was embellished with gold and colors similar to the ephod and was called the "essen ( $\left.\dot{\varepsilon} \sigma \eta^{\prime} \nu\right)$," which in Greek means "oracle ( $\lambda$ ó $10 v)$." This is, however, the function of the accessory, rather than a description. Josephus borrows the term from Exod 28:23 LXX, which in its turn calls the item "the oracle of judgment ( $\tau 0 \hat{v} \lambda$ 入

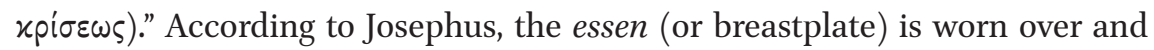
fastened to the empty space of the ephod by gold rings (

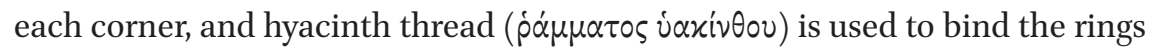
together. "Two sardonyxes fasten the epomis with a clasp on the shoulders, having each a golden end extending over them, being useful for [holding] the pins." ${ }^{\prime 7}$ On the sardonyxes are engraved in Hebrew the twelve names of Jacob's sons. Each precious stone bears the name of six sons, with the elder on the right shoulder. While the Hebrew text of Exodus attributes the oracular properties to the Urim and Thummim in the breastplate (Exod 28:30), ${ }^{48}$ Josephus ascribes oracular abilities, as observed above, to the whole structure of the accessory (Ant. 3.164-166).

On the breastplate are also attached twelve stones, which seem to have unearthly origins given that they are "outstanding in size and beauty, an ornament not obtainable by men because of the exceeding size of its value." The gemstones are arranged into four rows of three stones each and attached to the fabric with gold wires, "doing so in order that they should not slip out." Josephus then lists the stones of each breastplate's row: "The first triad is sardonyx, topaz, and emerald; the second includes carbuncle and jasper and sapphire; jacinth begins the third triad, then amethyst, third agate, being the ninth in the whole series; and chrysolite is the first in the fourth row, and after it onyx, then beryl, this being the last" (3.166-168). ${ }^{49}$

46 Trans. Begg and Spilsbury, Judean Antiquities 8-10. When describing the Essenes in War, Josephus states that the members of the group utter no mundane things before the sun rises, "but only certain ancestral prayers to him, as if begging him to come up." Also, when they excrete into holes, they wrap themselves entirely with their cloaks "so as not to outrage the rays of God" (J.W. 2.128, 148 [Mason]).

47 The Hebrew and Lxx texts diverge on the specification of the stone. While the Hebrew text of Exodus gives onyx, the Greek text refers to emerald ( $\sigma \mu \alpha \dot{\alpha} \alpha \alpha \gamma \delta \varsigma$ ) (28:9).

48 Exod 28:30 LXx refers to the Urim and Thummim as "the disclosure and the truth." For Philo's remarks, see $Q E 2.116$ and Moses 2.113.

49 In his account of the "true earth," Plato refers to three of the gemstones mentioned by Josephus: sardius, jasper, and emerald. According to the philosopher, these stones prized 
On each gemstone is engraved the name of one of Jacob's sons, and the names appear "according to the order in which each of them was born." Because of the weight of the breastplate, Josephus explains that two extra-large golden rings were added to the support. They "went into the web at the border of the essen, where it came up to the neck." These rings were entwined with gold cords, which went through to the top of the shoulders and fit into another ring sewn to the hem of the ephod at the back side. ${ }^{50}$ On the breastplate was sewn a belt $(\zeta \dot{\omega} \sim \eta)$ that was similar in colour to the first belt described in Ant. 3.154, along with gold. This belt, "after going around, was tied again at the seam and hung down. Golden sheaths took upon up the tassels at each end and encompassed them all" (3.169-171).

Josephus omits here any explanation of how the high priest's breastplate worked, but elsewhere he gives some details. He explains that "[Moses] left behind no starting-point for the evil deeds of prophets, if indeed there should be some such to abuse the dignity of God, but entrusted to God a sole ruler to be present at the sacred rites whenever He wished or not to be present." He explains that the sardonyx on the high priest's "right shoulder shone, with a radiance flashing and appearing to the one furthest away, although previously this was not present in the stone." In Josephus' view, this was not the most extraordinary thing about the breastplate, "for through the twelve stones that the high priest wore upon his breast stitched into the essen, God previously communicated victory to those about to go to war." When the radiance flashed from all the twelve stones, they knew that "God was at hand to aid them." Josephus also reports that the essen and the sardonyx ceased to function two hundred years before he wrote Antiquities, "since God was displeased at the violation of the laws" (3.214-218).52 Considering Josephus' own remarks, John

here on earth are also available in the "true earth." There, however, they have "smoothness and transparency and finer colours" (Phaed. nob-e).

50 Natalio Fernández Marcos explains that Josephus' editorial additions are included "to prevent the breastplate from slipping under the weight of the gems" ("Rewritten Bible?" 333).

$5^{1}$ Stuart D. Robertson suggests that the high priest's breastplate functioned "very much like that of the Delphic oracle which was consulted, among other questions, with questions having to do with the outcome of battles. The Greeks who would most honour this custom would be the ones who honoured the oracular powers of the Pythian priestess at Delphi" (Ancient Israelite Tabernacle, 230-31). While the utterances appear to apply to both oracles, Josephus refers to a high priest's accessory used by God to communicate his will, whereas the Delphic Pythia herself uttered prophecies under divine possession (Plutarch, Pyth. orac. 5·397.7).

52 Two hundred years before the completion of Antiquities would be about the time of John Hyrcanus' death in 104 BCE. See Feldman, Judean Antiquities, 289 n. 574. 
Hyrcanus I ( $r$. 134-104 BCE) seems to be the last person blessed with the gift of prophecy, at about the time the stones ceased to function as oracles. ${ }^{53}$

Josephus explains that "[Moses] set the essen in the middle of the outer vestment ( $\mu \dot{\varepsilon} \sigma \circ \nu$... $\tau \hat{\eta} \varsigma \dot{\varepsilon} \varphi \alpha \pi \tau i \delta \delta \varsigma)$ in the manner of the earth, for it has precisely the middle place" (3.185). He sustains the geocentric model here, viewing the earth as the center of the universe. The geocentric model, anticipating the Ptolemaic system, was the prevalent description of the cosmos in the Greco-Roman period. Although the theory was standardized in the second century $\mathrm{CE}$, as a result of the observations of the Alexandrian astronomer Claudius Ptolemy, ${ }^{54}$ its roots go back to the pre-Socratic philosophers. In the fourth century BCE, the theory is suggested in Plato's works, ${ }^{55}$ but his pupil Aristotle develops an elaborated earth-centered cosmology. For those philosophers, the earth is motionless and lies in the middle of the cosmos. All the other planets, the moon, and the sun revolve around it. ${ }^{56}$

We also learn regarding the belt of the breastplate, that "[Moses] signifies the Oceanus, for it, indeed, encloses everything" (3.184, modified). Once again, we find Josephus replicating the typical knowledge of cosmic geography of his time, which was understood by his Roman audience. ${ }^{57}$ By stating that God poured the sea around the earth (1.31), Josephus comes very close to the prevailing Greco-Roman view that the inhabited world was an island encircled by the sea, called Oceanus. ${ }^{58}$ Such an idea appears as early as the Homeric texts. In the Iliad, Oceanus is described as having enormous strength and deep-flowing waters, from whom all rivers and the entire sea have their waters (21.194), but it is the depiction of the shield of Achilles by Homer that holds our attention. According to the poet, the defensive armor was forged by Hephaistos and had the great power of the river Oceanus depicted around its outermost rim (18.6o6-6o7).

The two sardonyx stones on the shoulders which "[Moses] fastened with a brooch onto the garment of the high priest indicate the sun and the moon" (Ant. 3.185). ${ }^{59}$ Josephus' audience is aware that those two heavenly bodies are God's creation. Elsewhere he writes that "[God] adorned the heaven with the sun and moon ... assigning movements and courses for them by that the

\footnotetext{
53 See Josephus, Ant. 13.282-283, 299-30o; cf.J.W. 1.68-169.

54 See Ptolemy, Almagest $1.5\left[\mathrm{H}_{17}-2 \mathrm{O}\right]$.

55 See, for instance, Plato, Leg. 616b.

56 See Aristotle, Cael. 296b. See also Fraser, Cosmos, 13-34.

57 For other references to Oceanus in Josephus, see J.W. 2.363, 374; 3.107.

$5^{8}$ See, for instance, Herodotus, Hist. 4.36; Strabo, Geogr. 1.1.8; Seneca, Oedipus 504.

59 Even though Philo recognises that some think of the gemstones (emeralds) as the sun and the moon, he prefers to read them as the two hemispheres of the sky (Moses 2.122).
} 
revolutions of the seasons might be signified" (1.31). Josephus does not make clear why the stones could evoke the heavenly bodies, but Pliny's account of sardonyxes is noteworthy. The Roman author states that the sardonyx was esteemed in Rome and worn by the upper class, including the princeps Claudius. When describing the colors of the gemstone, Pliny explains that it has "a layer of carnelian resting on a layer of white, that is, like flesh superimposed on a human finger-nail, both parts of the stone being translucent" (Nat. 37.23.85 [Eichholz]). This explanation suggests that Josephus' readers may have understood the association of the colors of the stone with the sun (carnelian) and the moon (white).

Josephus explains that his reader could understand the twelve engraved gemstones on the breastplate as a portrayal of the lunar months of the year, as well the twelve signs of the zodiac: "whether someone would want to understand the months or the same number of the stars, which the Greeks call the circle of the zodiac, he would not err in his interpretation" (Ant. 3.186). Earlier, in his retelling of Joseph's stellar dream, Josephus already connects the twelve patriarchs with stars. We also learn from the same dream that the sun and the moon occupy a position superior to that of the stars, which may explain why Josephus assigns those cosmological readings to the high priest's accessories. Josephus' Joseph explains that the moon and the sun represent his mother and father, "since the one gave increase to and nourished all things, and the other gave shape to them and infused other strength in them." The stars represented Joseph's brothers, "for, indeed, they were eleven in number and like the stars, they derived their strength from both the sun and moon" (2.13-16).

For Stuart D. Robertson, Josephus' remark on the zodiac "is suggestive that he believed the heavenly bodies played some role in the revelation of Divine providence, or at least that he wished to draw on his pagan readers' belief in the influence of the stars, in order to make them think well of ... the High Priest's breastpiece." ${ }^{60}$ It appears, however, that the twelve zodiacal signs in the high priest's breastplate underscore God's supreme control of the stellar movements. With this cosmological interpretation, Josephus seems to suggest that the worshipper of God would find assurance in revering a deity who was unaffected by astrological fate. ${ }^{61}$ As his audience will observe all over Antiquities, God is the father of all $(2.152 ; 5.97 ; 12.23)$, creator of all creatures $(4.262 ; 12.22)$, and lord and king of the universe $(1.72 ; 4.40 ; 14.24 ; 20.90)$. He is in control of everything and everyone $(4.41 ; 2.129 ; 5.109 ; 6.131 ; 8.108 ; 12.20-21 ; 17.128)$. Besides,

6o Robertson, Ancient Israelite Tabernacle, 270.

61 See, for example, this explanation for the zodiac on the representations of the Ephesian Artemis (Arnold, Ephesians, 28). 
given that Josephus ascribes oracular abilities to the breastpiece, his Roman audience may have understood the accessory as an astrological tool for the prediction of human events, with the difference, however, that God, and no other celestial forces, revealed his will through the device. ${ }^{62}$

Priestly breastplates were known in Rome. Titus Livius writes that the priests of Mars, called Salii, were distinguished by their embroidered tunic and over it a bronze breastplate (1.1.20). It could also be that Josephus' audience would recognize in the high priest's breastplate a Roman muscle cuirass, like those connected with the Roman principes. The famous cuirassed statue of Augustus at Prima Porta, for instance, appears to depict Augustus' godlike dominance over the earth and heavens, including the sun god Sol in his quadriga, the moon goddess Luna, the god Caelus (personification of sky), and the goddess Tellus Mater (earth). In Paul Zanker's view, "the astral gods, with their perpetual rising and sinking, symbolize eternity. Together with the sky god and the earth goddess they emphasize the cosmic character of space and time on the relief." ${ }^{33}$ Moreover, the representation of deities with a starry cuirass was known in the Eastern part of the empire. A relief found in Dura-Europos displays the god Aphlad wearing a breastplate covered in brilliant stars. ${ }^{64}$

The high priest's cap ( $\delta$ $\pi \hat{\imath} \lambda \circ \varsigma$ ) is the last item commented on by Josephus. He explains that the cap was similar to that of the ordinary priest, but made of hyacinth embroidery and worn above the first cap. The accessory was sur-

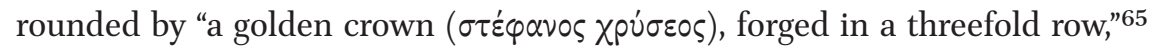
and blooming above it a golden calyx ( $\chi \dot{\alpha} \lambda \nu \xi \chi \chi^{\prime} \cup \dot{\sigma \varepsilon}$ ), recalling a plant called

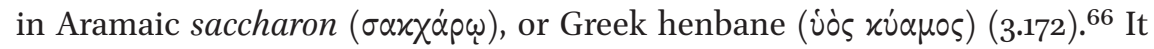
was on the model of this plant that the "crown ( $\sigma \tau \dot{\varepsilon} \varphi \alpha \nu \circ \varsigma)$ was forged extending

62 That astrological knowledge was closely linked to priestly circles is manifest in Hellenistic Egypt, where, "during this period, astronomy and astrology remained subjects of the highest interest within the native Egyptian priesthood serving the traditional Egyptian gods" (Lieven, "Hellenistic Astronomy," 411).

63 Zanker, Power of Images, 188-92. See also Price, Rituals and Power, 185-86.

64 See Moralee, For Salvation's Sake, 8o. A headless statue of a Julio-Claudian princeps found in the theatre of Caere in Etruria wears a cuirass displaying a solar design motif (Champlin, Nero, 119).

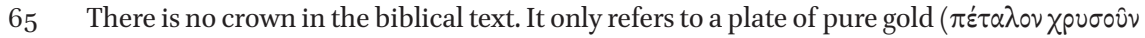

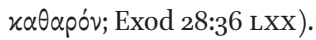

66 At this point, Josephus interrupts his narrative for an excursus on the characteristics of henbane. He justifies the detailed description with the admission that some of his readers are ignorant of the features of the plant (Ant. 3.173-177). The henbane (Hyoscamus niger) was a hallucinogenic plant used in the eastern Mediterranean for medicinal (sedation and pain relief) and ritual purposes (probably within the mystery rites) (Castelli, Antichità Giudaiche, 271-72; Gicheva-Meimari, "Chest Crossbands." 
all the way from the nape of the neck to each of the two temples [of the head]." The calyx, also called the ephielis ( $\dot{\varepsilon} \varphi(\varepsilon \lambda i \varsigma)$, did not cover the forehead. Josephus also mentions a golden plate on which were engraved the most "sacred letters with the name of God" (3.178). He, however, does not say by which word God should be called. Elsewhere Josephus states that God revealed to Moses his name. However, the name was not for men's ears, and he, Josephus, was forbidden to speak about it $(2.276) .67$

Josephus explains that the high-priestly headgear seems to him a symbol of "heaven, which has been fashioned to be hyacinth. Otherwise, the name of God, adorned with a headband — and that of gold — would not have been set upon it, on account of the radiance in which the Divinity most rejoices" (3.187). Although Josephus does not give further details of this symbolic approach, a Roman reader might have understood the interpretation of the accessory as representing heaven not only because of its colour, but also by the design of the crown in the shape of a henbane's calyx could suggest the sun's rays. ${ }^{68}$

Robertson suggests that Josephus was influenced in his description of the three-tiered crown by Philo, "who found mystical Divine symbolism in the number three." ${ }^{69}$ Although Philo refers to the symbolism of the number three for God ( $Q G$ 4.2), in his description of the high priestly attire, he mentions only a single crown (Moses 2.116). Considering that no other ancient source known to us describes the high priest's headgear in such terms, Étienne Nodet suggests that Josephus is referring to a type of crown worn by the high priest in his own lifetime and which he projects onto Moses' time. ${ }^{70}$ Josephus could also be idealizing the high priest's crown for his audience. The threefold row design could indicate God's dominance over the three cosmological regions: sky, earth, and sea. The use of multiple crowns as a statement of authority over several areas has been known since ancient Egypt. Under the Ptolemaic dynasty, those ornamental headdresses were one of the few Egyptian features still occurring in Greek-style royal images. ${ }^{71}$

By putting on the golden crown, the high priest is conferred with emblems of divine authority. This is especially clear for Josephus' audience in the account of Alexander the Great's encounter with the Judean high priest outside Jerusalem. Josephus writes that when the Greek ruler saw the high priest in his

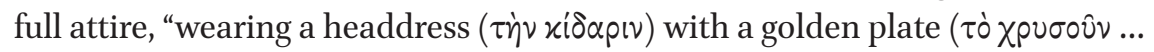

67 In another place, Josephus says that the crown, "on which Moses wrote [the name of] God ... survived down till day" (Ant. 8.93).

68 Hayward, Jewish Temple, 150-51.

69 Robertson, Ancient Israelite Tabernacle, 236-37.

$70 \quad$ Nodet, Antiquités Juives, 161 n. 6.

71 See, for instance, Stanwick, Portraits of Ptolemies, 34-35. 
$\left.\tilde{\varepsilon}^{2} \lambda \alpha \sigma \mu \alpha\right)$ on it on which was inscribed the name of God, he approached alone and prostrated himself before the name and first greeted the high priest." When Parmenion questioned him about his behavior before the high priest, Alexander answered: "It was not before him that I prostrated myself but the God of whom he has the honor to be high priest" (Ant. 11.331-333 [Marcus, modified]). For Josephus, the high priest's golden crown was a symbol of divine glory. The radiance of the golden headgear evoked the presence of God with the high priest.

The use of honorary crowns and diadems by priests was a practice common in the Greco-Roman period. Crowns were sacred to the gods, and they were an appropriate item worn by the priests to perform rituals before the deities. Wreaths were sacred because they symbolized the gods whom the priests served. They could be made of flowers or precious metals, such as gold, which was considered the appropriate expression of divinity. ${ }^{72}$

To sum up, for Josephus, the entirety of the cosmos, as created by God and known by his Roman audience from Ant. 1.27-35, is contained within the high priest's clothing. Following the prevailing worldview of the first century, Josephus assigns each piece of the clothing to a region of the universe. The ephod with its breastplate and belt is the center of this cosmological geography. Made of exquisitely woven material, they indicate the basic elements of nature. The breastplate, worn over and fastened to the space in the middle of the ephod, corresponds to the earth that stands in the center of the universe. The belt of the ephod encloses everything, as Oceanus encircles the earth. On the breastplate are twelve gemstones representing the constellations seen in earth's night sky. While the linen chiton reaching to the feet characterizes the earth, the second, hyacinth chiton, in the manner of the vault of the heaven enfolding the earth, encloses the first chiton. The embroidered figures on the border of the hyacinth chiton resemble natural phenomena that occur in the earth's atmosphere. The upper part of the apparel represents the heavenly regions. The two sardonyxes fastened on the shoulders signify the two brightest and the most massive objects in our earth's sky, the sun and moon; the cap and the golden crown indicate heaven, a region inaccessible to human beings and where God dwells. ${ }^{73}$ The influence of Stoic ideas on the conception of the high priest as a microcosm is evident here. For the Stoics, the human body was perceived as a microcosm copying the macrocosm of the universe. "There is a

72 See Miller, "Ependytes," 320; Stevenson, "Golden Crown Imagery," 257-63. On the use of Hellenistic-style radiate crowns by Hellenistic kings and Roman principes, see Thonemann, Hellenistic World, $156-58$.

For an alternative explanation, see Gussmann, Priesterverständnis, 393-94. 
'sympathy' between celestial and earthly realities which imply a unity of the whole and a solidarity of the parts." ${ }^{74}$

\section{$2 \quad$ Clothing Imagery in the Greco-Roman Period}

Josephus was by no means alone in portraying a mortal's apparel in cosmic terms; an examination of relevant literary and archaeological evidence indicates that other communities within and beyond the Mediterranean basin also represent royal and divine robes with rich sets of symbolic meanings. One of the oldest pieces of evidence found in Greek literature, for instance, occurs in Homer's Iliad. Homer depicts the shield forged by god Hephaestus to Achilles as bearing an image of the universe. ${ }^{75}$ The poet writes that Achilles' personal armor was made of five layers, and on it, Hephaestus placed several ornaments:

He made the earth and the sky and the sea and the unwearied sun and the full moon and all the constellations with which the sky is crowned the Pleiades and the Hyades and mighty Orion and the Bear, which men also call the Wagon, which always goes around in the same place, watching Orion.

HOMER, Il. 18.478-489 (Powell)

The Heraclitus who was probably Josephus' contemporary reads Homer's characterization of Achilles' armor symbolically: "In forging the Shield of Achilles as an image of the revolution of the cosmos, he has shown by clear evidences how the universe originated, who is its creator, and how its different parts were formed and separated." For Heraclitus, the shield's bronze, tin, silver, and gold indicated the four elements. The spherical shape of the weapon hinted at the cosmic circle, and the five layers of the shield denoted the zones of the cosmos (All. 43-50 [Russell and Konstan]).

In Apuleius' Metamorphoses, the Roman author vividly describes, from his protagonist's mouth, the clothing of the goddess Isis as mirroring the cosmos. Lucius, the leading character, in a dream sees Isis in all her splendor. He says that a crown woven with different flowers encircled the top of the goddess' head. At the midpoint of the crown, above her forehead, "a flat round disc like a mirror—or rather a symbol for the moon—glistened with white light." The

74 Hadas-Lebel, Philo of Alexandria, 170; Heilen and Greenbaum, "Astrology," 123-24.

75 Apollonius Rhodius' Argonautica seems to indicate a similar treatment in his portrayal of the cloak of the Greek hero Jason (1.721-767). See also Shapiro, “Jason's Cloak." 
right and left side of the crown were adorned with snakes and ears of wheat. Her robe was made of sheer linen of many colors, "here shining with white brilliance, there yellow with saffron bloom, there flaming with rosy redness."76 Lucius, however, was perplexed by "a deep black cloak gleaming with dark sheen, which was wrapped about her, running under her right arm up to her left shoulder, with part of its border let down in the form of a knot; it hung in complicated pleats, beautifully undulating with knotted tassels at its lower edge" (Metam. 11.3 [Hanson]).

He adds that "along the embroidered border and over the surface of the cloak glittering stars were scattered, and at their center, the full moon exhaled fiery flames." On the hem of the robe, "a garland of flowers and fruits of every kind was attached to it with an inseparable bond." Isis presents herself to Lucius as a "mother of the universe, mistress of all the elements, and first offspring of the ages; mightiest of deities, queen of the dead, and foremost of heavenly beings." As a goddess who has power over all the cosmic regions, she says: "with my nod I rule the starry heights of heaven, the health-giving breezes of the sea, and the plaintive silences of the underworld" (Metam. 11.4-5 [Hanson]).

In some representations of the god Mithras, his attire depicts cosmic imagery, as in the Mithraeum Barberini in Rome. In the painting, Mithras wears Persian trousers and a Phrygian cap in blue, along with a mantle in dark red. The mantle, designed as the celestial sphere, is decorated with seven stars scattered over it. The fresco in Mithraeum at Marino, in its turn, displays stars in all of Mithras' clothing, including cap, tunic and cloak. Modern scholars have taken the blue colour in the attire as the symbol of the sky, and the red colour as the burning sky or ether. The cloak represents the vault of heaven with the seven planets. In some other representations of Mithras, the trousers are adorned with small rosettes, which are the symbol of the sun. ${ }^{77}$

The cult statue of Artemis Ephesia exhibits her neck decorated with extravagant jewelry, including Nike and signs of the zodiac. Similarly, a secondcentury CE stele from Argos depicts the goddess Selene with a lunar tiara, with seven large stars around her head and shoulders, and the twelve signs of the zodiac encircling the outer rim of the niche. According to Stephen J. Patterson, this cosmic motif "has the effect of universalizing the sovereignty of the deity, now seen as lord of the heavens, who controls the progression of time and

76 Plutarch states that Isis' clothes are dyed in many colours, "for her power is concerned with matter which becomes everything and receives everything, light and darkness, day and night, fire and water, life and death, beginning and end" (Is. Os. 382c [Babbitt]).

77 See Sánchez, "Dress and Colour," 125; Clauss, Roman Cult, 84. In late antiquity, the god Attis is described with a Phrygian cap adorned with stars of the visible sky (Julian, Orationes 5.165c; see also 5.171a). 
events." ${ }^{78}$ The rich iconographic repertoire of the cult images of Aphrodite of Aphrodisias is another example of an existing tradition of representing deities with universal powers in the Greco-Roman period. The statue presents the goddess in a long chiton enclosed by a stiff ependytes that is ornamented in four horizontal layers. On the first, upper layer is depicted the Three Graces. On the second are represented Selene and her brother Helios. The third shows Aphrodite mounted on the mythical Capricorn (sea-goat) and followed closely by a dolphin. On the lowest stratum are three Erotes offering incense. Those four zones are regarded as the power of Aphrodite over the four cosmic regions. The Three Graces, symbols of fertility and growth, represent the earth. Selene, the goddess of the moon, and her brother Helios, the sun god, represent the sky. Aphrodite riding over the waves on the sea-goat represents the sea, and three Erotes burning incense, a typical motif found on funerary reliefs, suggest the underworld. Even though this cult image was conceived in Anatolia in the late Hellenistic period, it was widespread in Josephus' time. ${ }^{79}$

Some of the representations of Jupiter Optimus Maximus Heliopolitanus, worshipped in Baalbek (Syria), also display astrological motifs in his garments. Like Aphrodite of Aphrodisias, those miniature images feature Jupiter richly dressed in an ependytes over a military cuirass. On the front side of the tightfitting robe, the top portion shows Helios and Selene. On the lower stratum appear the busts of the other five planetary deities (Mars, Mercury, Jupiter, Venus, and Saturn). The seven planetary gods signify the seven-day week and allude to Jupiter's role as a god of the cosmos. ${ }^{80}$

Not only deities and heroes were depicted wearing the cosmos. Greco-Roman rulers are also said to have garments that imitated the nature of the universe. Plutarch, for instance, writes that the Hellenistic King Demetrius Poliorcetes had an extravagant supply of cloaks, headpieces, and shoes made of hyacinth threads and gold. One "cloak ( $\chi \lambda \alpha \mu u \dot{s})$ " in particular was a splendid creation in "the likeness of the cosmos" and "the vault of heaven" (Demetr. 414-415). ${ }^{81}$ Suetonius and Pausanias write about a golden diadem of the sun god, purple garment, and a cloak adorned with golden stars worn by Nero after celebrating his Olympic victories (Suetonius, Nero 25.1; Pausanias, Descr. 2.17.6). Those fancy dresses were meant to indicate the universalistic power of those rulers.

\footnotetext{
78 Patterson, "Votive Relief," 440.

79 See Edwards, Religion and Power, 58; Ridgway, Hellenistic Sculpture, 115-16.

8o See Long, Twelve Gods, 290-93; Kropp, "Jupiter of Heliopolis," 233-34.

81 Athenaeus of Naucratis writes that the heavens were woven into the cloak's king, having the stars and the signs of the zodiac embroidered in gold (Deipn. 12).
} 
Our assessment of Ant. 3.151-180, 184-187 shows Josephus' attempt to provide a vivid description of the high priest's apparatus. In his reworking of the Exodus narrative of the making of the high priestly attire, Josephus carefully describes each item of clothing and interprets most of them as symbolic aspects of the universe. Even though Josephus devotes considerable lines to the portrayal of the high priest, it has received little attention from modern scholars. Of those who venture to study the account, few address the question of Josephus' audience. We have observed that Josephus' elaborate depiction of the high priestly clothing as an image of the universe only makes sense when we understand to whom the author speaks.

Given that Josephus devoted himself to literary pursuits in Rome and that his texts certainly appealed to a local audience in the capital, the high priestly attire's symbolism conveys important information his readership would have discerned. The portrait Josephus paints of the high priest's vestments serves to at least one crucial purpose: to show the power of the Judean God. This is especially evident when we examine the lavish description of the sacred garment within the narrative of the setup of the tent in Ant. 3.100-187. According to Josephus, the portable temple with its furnishings and personnel are purposefully arranged and operated in complete harmony with the universe (3.180).

As we have observed, the reading of the tent and everything within it as the embodiment of the cosmos is a thread of an intricate tapestry woven by Josephus, who attempts to harmonize the Judean politeia, which was given by God to Moses, with the notion of universal law. All through Antiquities, Josephus makes clear to his Roman audience that the Judean god made the cosmos and everything in it. Considering that the tent was the place where God chose to dwell and from which he controlled human affairs, the cult site, its implements, and especially the priests' attire embodied the universe as created and sustained by God. Josephus shows his Roman audience that the tent reflects the vastness and greatness of heaven and earth. Therefore, Josephus' symbolic understanding of the high priestly attire should be understood in light of the powerful Judean deity he sought to depict.

Given the power and prestige of the high priest in leading the rituals and his role as the only representative of God on earth, his clothing embodies a map of the cosmos. This garb includes, among other things, the cosmic geography (sea, earth, and sky), the four elements used by God as ingredients in his recipe for making up humans and all other creatures, and the heavenly bodies. Josephus not only electrifies his audience with his vivid portrait of the 
sacred garments as a snapshot of God's creation but also unveils through these descriptions the deity's omnipotence. God's manifestation through thunder and flashes of lightning, and his control of the stellar movements expresses the idea that fate was not written in the stars, but controlled by God alone.

Josephus' remarks on the high priestly attire should be read in the light of a widespread tendency in Greco-Roman cultures; he follows other contemporary thinkers who attempt to place their deities or rulers into a universal context. These archaeological findings and Greco-Roman texts show humans and deities with highly symbolic clothing. The sumptuous, cosmic ornaments and clothes are shown or described not only to impress and delight the viewer or reader, but also to declare the wearer as a god or ruler whose power extends over all. Josephus was undoubtedly acquainted with this tradition, and may have used some of those cosmological features in vogue in Rome for his rendering of the high priestly garb as an indication of God's universal sovereignty.

\section{Bibliography}

Apuleius. Metamorphoses (The Golden Ass), vol. 2 Books 7-11, trans. J. Arthur Hanson (Cambridge: Harvard University Press, 1989).

Arnold, Clinton E. Ephesians: Power and Magic. The Concept of Power in Ephesians in Light of Its Historical Setting (Cambridge: Cambridge University Press, 1989).

Aune, David. Revelation 1-5 (Grand Rapids: Zondervan, 1997).

Begg, Christopher T., and Paul Spilsbury. FlaviusJosephus:Translation and Commentary, vol. 5 Judean Antiquities, Books 8-10 (Leiden: Brill, 2005).

Bilde, Per. Flavius Josephus between Jerusalem and Rome. His Life, His Works and Their Importance (Sheffield: Sheffield University Press, 1988).

Brown, Eric. "The Emergence of Natural Law and the Cosmopolis." In The Cambridge Companion to Ancient Greek Political Thought, ed. Stephen Salkever (Cambridge: Cambridge University Press, 2009).

Burkert, Walter. Greek Religion: Archaic and Classical (Oxford: Blackwell, 1985).

Castelli, Silvia. Il terzo libro dell Antichità Giudaiche di Flavio Giuseppe e la Bibbia: Problemi storici e letterari. Traduzione e commento (Como: New Press, 2002).

Champlin, Edward. Nero (Cambridge: Harvard University Press, 2003).

Clauss, Manfred. The Roman Cult of Mithras: The God and His Mysteries, trans. Richard Gordon (New York: Routledge, 2001).

Cook, John G. The Interpretation of the Old Testament in Greco-Roman Paganism (Tübingen: Mohr Siebeck, 2004). 
Danby, Herbert. The Mishnah: Translated from the Hebrew with Introduction and Brief Explanatory Notes (Oxford: Oxford University Press, 1933).

Edwards, Douglas R. Religion and Power: Pagans, Jews, and Christians in the Greek East (New York: Oxford University Press, 1996).

Feldman, Louis H. Josephus's Interpretation of the Bible (Berkeley: University of California Press, 1998).

Feldman, Louis H. Flavius Josephus: Translation and Commentary, vol. 3 Judean Antiquities 1-4 (Leiden: Brill, 2000).

Fernández Marcos, Natalio. "Rewritten Bible or Imitatio? The Vestments of the High-Priest." In Studies in the Hebrew Bible, Qumran, and the Septuagint Presented to Eugene Ulrich, ed. Peter W. Flint, Emanuel Tov, and James C. VanderKam (Leiden: Brill, 2006), 321-36.

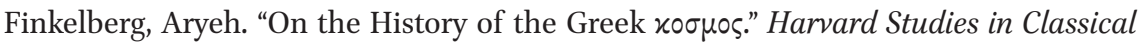
Philology 98 (1998), 103-36.

Fraser, Craig G. The Cosmos: A Historical Perspective (Westport: Greenwood, 2006).

García Sánchez, Manel. "The Dress and Colour of Mithraism: Roman or Iranian Garments?" In Kleidung und Identität in religiösen Kontexten der römischen Kaiserzeit, ed. Sabine Schrenk (Regensburg: Schnell \& Steiner, 2012), 123-34.

Gicheva-Meimari, Rossitsa. "Chest Crossbands: Realia of Religious Belief and Practice in Ancient and Byzantine Thrace." In Byzantine Thrace: Evidence and Remains: Proceeding [of the] 4th International Symposium on Thracian Studies, Komotini, 18-22 April 2007, ed. Charalambos Bakirtzis, Nikos Zekos, and Xenophon Monarios (Amsterdam: Hakkert, 2011), 359-81.

Gussmann, Oliver. Das Priesterverständnis des Flavius Josephus (Tübingen: Mohr Siebeck, 2008).

Hadas-Lebel, Mireille. Philo of Alexandria: A Thinker in the Jewish Diaspora (Leiden: Brill, 2012).

Haran, Menahem. Temples and Temple-Service in Ancient Israel: An Inquiry into Biblical Cult Phenomena and the Historical Setting of the Priestly School (Winona Lake: Eisenbrauns, 1985).

Hayes, Christine. What's Divine about Divine Law? Early Perspectives (Princeton: Princeton University Press, 2015).

Hayward, C. T. Robert. The Jewish Temple: A Non-Biblical Sourcebook (London: Routledge, 1996).

Heilen, Stephan, and Dorian Gieseler Greenbaum. "Astrology in the Greco-Roman World." In Time and Cosmos in Greco-Roman Antiquity, ed. Alexander Jones (Princeton: Princeton University Press, 2016), 123-41.

Holladay, Carl H. Theios Aner in Hellenistic-Judaism: A Critique of the Use of this Category in New Testament Christology (Missoula: Scholars Press, 1977). 
Homer. The Iliad: A New Translation, trans. Barry B. Powell (New York: Oxford University Press, 2014).

Huitink, Luuk, and Jan Willem van Henten. "The Publication of Flavius Josephus' Works and Their Audiences." Zutot 6 (2009), 49-6o.

Josephus. Jewish Antiquities, vol. 1 Books 1-3, trans. H.St.J. Thackeray (Cambridge: Harvard University Press, 1930).

Josephus. Jewish Antiquities, vol. 4 Books 9-11 trans. R. Marcus (Cambridge: Harvard University Press, 1930).

Kropp, Andreas J.M. "Jupiter, Venus and Mercury of Heliopolis (Baalbek)." Syria 87 (2010), 229-64.

Lieven, Alexandra von. "Hellenistic Astronomy and the Egyptian Priest." In Hellenistic Astronomy: The Science in Its Contexts, ed. Alan C. Bowen and Francesca Rochberg (Leiden: Brill, 2020), 411-25.

Long, Charlotte R. The Twelve Gods of Greece and Rome (Leiden: Brill, 1987).

Lovén, Lena Larsson. "On Priests, Priestesses, and Clothing in Roman Cult Practices." In Textiles and Cult in the Ancient Mediterranean, ed. Cecilie Brøns and Marie-Louise Nosch (Oxford: Oxbow, 2017), 135-41.

Mader, Gottfried.Josephus and the Politics of Historiography: Apologetic and Impression Management in the Bellum Judaicum (Leiden: Brill, 2000).

Marconi, Clement. "Kosmos: The Imagery of the Archaic Greek Temple." REs: Anthropology and Aesthetics 45 (2004), 211-24.

Martzavou, Paraskevi. "Isis Aretalogies, Initiations, and Emotions: The Isis Aretalogies as a Source." In Unveiling Emotions: Sources and Methods for the Study of Emotions in the Greek World, ed. Angelos Chaniotis (Stuttgart: Steiner, 2012), 267-91.

Mason, Steve. Introduction to Flavius Josephus: Translation and Commentary, vol. 3 Judean Antiquities 1-4, by Louis H. Feldman (Leiden: Brill, 2000).

Mason, Steve. "Of Audience and Meaning: Reading Josephus' Bellum Judaicum in the Context of a Flavian Audience." In Josephus and Jewish History in Flavian Rome and Beyond, ed. Joseph Sievers and Gaia Lembi (Leiden: Brill, 2005), 71-10o.

Mason, Steve. Flavius Josephus: Translation and Commentary, vol. 1b Judean War 2 (Leiden: Brill, 2008).

Mason, Steve. "Josephus, Publication, and Audiences: A Response." Zutot 8 (2011), 81-94.

Mason, Steve. A History of the Jewish War, A.D. 66-74 (Cambridge: Cambridge University Press, 2017).

Miller, Margaret C. "The Ependytes in Classical Athens." Hesperia: The Journal of the American School of Classical Studies at Athens 58 (1989), 313-29.

Moralee, Jason. For Salvation's Sake:Provincial Loyalty, Personal Religion, and Epigraphic Production in the Roma and Late Antique Near East (New York: Routledge, 2004). 
Mathews, Danny. Royal Motifs in the Pentateuch Portrayal of Moses (New York: T\&T Clark, 2012).

Nodet, Étienne. Les Antiquités Juives, vol. 1 Livres I à III (Paris: Cerf, 1990).

Osborne, Grant R. Revelation (Grand Rapids: Baker Academic, 2002).

Patai, Raphael. Man and Temple: In Ancient Jewish Myth and Ritual (London: Nelson, 1947).

Patterson, Stephen J. "A Note on an Argive Votive Relief of Selene." The Harvard Theological Review 78 (1985), 439-45.

Plutarch. Moralia, vol. 5 Isis and Osiris. The E at Delphi. The Oracles at Delphi No Longer Given in Verse. The Obsolescence of Oracles, trans. Frank Cole Babbitt (Cambridge: Harvard University Press, 1936).

Price, Jonathan J. "The Provincial Historian in Rome." In Josephus and Jewish History in Flavian Rome and Beyond, ed. Joseph Sievers and Gaia Lembi (Leiden: Brill, 2005), $101-18$.

Price, Simon R.F. Rituals and Power: The Roman Imperial Cult in Asia Minor (Cambridge: Cambridge University Press, 1986).

Ridgway, Brunilde Sismondo. Hellenistic Sculpture, vol. 1 The Styles of ca. 331-200 B.c. (Madison: University of Wisconsin Press, 2002).

Robertson, Stuart Dunbar. The Account of the Ancient Israelite Tabernacle and First Priesthood in the Jewish Antiquities of Flavius Josephus, Thesis (Annenberg Research Institute, 1991).

Russell, Donald A., and David Konstan. Heraclitus: Homeric Problems (Atlanta: Society of Biblical Literature, 2005).

Sanders, E.P.Judaism: Practice and Belief, 63 B

Shapiro, H.A. "Jason's Cloak." Transactions of the American Philological Association (1974-2014) 110 (1980), 263-86.

Shlezinger-Katsman, Dafna. "Clothing." In The Oxford Handbook of Jewish Daily Life in Roman Palestine, ed. Catherine Hezser (Oxford: Oxford University Press, 2010), $362-81$.

Stalley, R.F. An Introduction to Plato's Laws (Oxford: Blackwell, 1983).

Stanwick, Paul E. Portraits of the Ptolemies: Greek Kings as Egyptian Pharaohs (Austin: University of Texas Press, 2002).

Stevenson, Gregory M. "Conceptual Background to Golden Crown Imagery in the Apocalypse of John (4:4, 10; 14:14)." Journal of Biblical Literature 114 (1995), 257-72.

Thonemann, Peter. The Hellenistic World: Using Coins as Sources (Cambridge: Cambridge University Press, 2015).

Valette-Cagnac, Emmanuelle. La lecture à Rome: rites et pratiques (Paris: Belin, 1997).

Warren, Meredith. "A Robe Like Lightning: Clothing Changes and Identification in Joseph and Aseneth." In Dressing Judeans and Christians in Antiquity, ed. Kristi 
Upson-Saia, Carly Daniel-Hughes, and Alicia J. Batten (Surrey: Ashgate, 2014), 137-53.

Weissenrieder, Annette. "A Roadmap to Heaven: High-Priestly Vestments and the Jerusalem Temple in Flavius Josephus." In Beyond Priesthood:Religious Entrepreneurs and Innovators in the Imperial Era, ed. Richard L. Gordon, Georgia Petridou, and Jörg Rüpke (Berlin: De Gruyter, 2017), 157-83.

Wright, M.R. Cosmology in Antiquity (New York: Routledge, 1995).

Zanker, Paul. The Power of Images in the Age of Augustus (Ann Arbor: University of Michigan Press, 1988). 